\title{
ANALYSIS OF CERTAIN PHYSICAL PROPERTIES OF FOUR ROCK MATERIALS
}

Original scientific paper

UDC: 622.349 .5

https://doi.org/10.18485/aeletters.2020.5.4.1

\author{
Vukić Lazićc ${ }^{1}$, Dušan Arsić ${ }^{1}$, Milan Mutavdžić², Ružica R. Nikolić3 ${ }^{3}$ Branislav Hadzima \\ ${ }^{1}$ Faculty of Engineering, University of Kragujevac, Kragujevac, Serbia \\ ${ }^{2}$ High Technical school, Leposavić, Serbia \\ ${ }^{3}$ Research Center, University of Žilina, Žilina, Slovakia
}

\begin{abstract}
:
This paper presents an analysis and the test results of certain physical properties of the rock materials excavated from quarries in Serbia. The four rock aggregates, considered in this analysis, are used for building the driveway constructions' layers on roads, streets, airports and base layers on railways. To that purpose, both the general and specific technical properties (petrographic, physical, mechanical and technological) of those rocks must be known to users. The four rocks, whose physical properties are analyzed, are the most important types of the building stones: limestone, dolomite marble, calcite-dolomite marble and andesite. Their physical properties tested included volumetric mass, specific mass (density), porosity and water absorption. The service life, reparation jobs and maintenance procedures of the construction machinery parts, which come into direct contact with building materials like rocks and stones, strongly depend on those stones' properties. The four tested rock materials belong into a group of the massive rocks with various porosities and tendency to absorb water.
\end{abstract}

ARTICLE HISTORY

Received: 22.09.2020.

\section{KEY WORDS}

Rock materials, aggregates, minerals, physical properties, testing procedures

\section{INTRODUCTION}

The working parts of the construction machinery in civil engineering are frequently exposed to direct contact with various types of building materials (stone, gravel, soil, asphalt, concrete, etc.), as well as with water. Thus, the construction machines, as well as their elements, used in producing, transport and building-in of those materials, are exposed to different kinds of extremely heavy loads and stresses. They are simultaneously exposed to processes of intensive wear and corrosion and occasionally or constantly to impact loads of different intensities. The quality of the working parts of the construction machinery, which are subjected to direct contact with building materials, directly influence the service life of that machinery, as well as the efficiency of its utilization capacity.
The main causes of the construction machinery working parts damages were subjects of research of authors of this article [1, 2], as well as many others [3-5]. The general conclusion, on which the majority of authors agree, is that the service life and intensity of wear of the construction machinery mainly depend on physical and mechanical properties of the rock materials and their aggregates with which they come into contact [6-12].

In addition, from the tribological point of view, the tribo-mechanical systems of those working parts consist of the metal working element, building (rock) material and environment, which is another reason for performing the mentioned experimental investigations of the rock materials' properties. Knowing those properties enables identifying the ways to extend the service life of the construction machinery elements, how to 
facilitate exploitation of the rock materials from the queries, as well as their application for the road constructions, [13-15].

The most significant technical properties of rocks are petrographic, physical, mechanical and technological, Table 1. [2, 16]. Those properties drastically change due to influence of water, extreme temperatures (either low - frost or high heat), thus knowing mechanisms of those influences is of utmost importance. In addition, properties of rocks are directly influenced by properties of minerals that make their composition. All the minerals that are constituents of rocks can be classified, according to their chemical composition, into seven groups: silicates, carbonates, oxides, sulphates, sulphides, chlorides and hydro-oxides. According to the way of creation, all the rocks can be classified into three large groups: magmatic (eruptive), sedimentary and metamorphic.

Table 1. Types of rock properties.

\begin{tabular}{|l|l|}
\hline Group & Properties \\
\hline Petrographic & Mineral composition, Structure, Texture \\
\hline Physical & $\begin{array}{l}\text { Specific mass (density), Specific volume, Porosity, Compactness, Water absorption, Compressibility, } \\
\text { Permeability, Humidity, Capillarity, Stickiness, Swelling, Ventilability, Wave velocity }\end{array}$ \\
\hline Mechanical & $\begin{array}{l}\text { Compressive Strength, Tensile Strength, Bending strength, Shear strength, Elasticity Modulus, } \\
\text { Poisson's Ratio, Wear resistance, Strain at Failure, Hardness, Impact toughness, Fracture Toughness }\end{array}$ \\
\hline Technological & Machinability, Drillability, Fragility, Looseness, Friability \\
\hline
\end{tabular}

Analysis of the selected rock physical properties was done for materials from four sites in Republic of Serbia: limestone - site "Vučjak", dolomite limestone - site "Samar", calcite-dolomite limestone - site "Gradac" and andesite - site "Šavnik". Obtained results can be useful for analysis of influence of the rock materials' quality on stability of terrain where the construction is done, as well as on possibility for application and proper exploitation of the construction machinery during the production, transport and building-in of those materials and their aggregates.

\section{PETROGRAPHIC PROPERTIES OF INVESTIGATED ROCK MATERIALS}

The petrographic properties of rocks, which are the most important for technical applications, are the mineral composition, structure and texture. The rock structure implies its shape, size and way of bonding of its mineral grains. The structure is usually considered separately from the way of the rock's creation and it can be crystallite, porphyritic and clastic. The rock texture implies the placement and distribution of minerals of its composition, as well as the presence of pores and micro-cracks. The texture can be massive, fluid, vesicular, striped, breccia and slate, $[2,13]$.

\subsection{Limestone - site "Vučjak"}

This site is mainly consisting of the limestone, Figure 1 . The structure of this rock is crystallite to micro-crystallite. The texture is massive and compact.

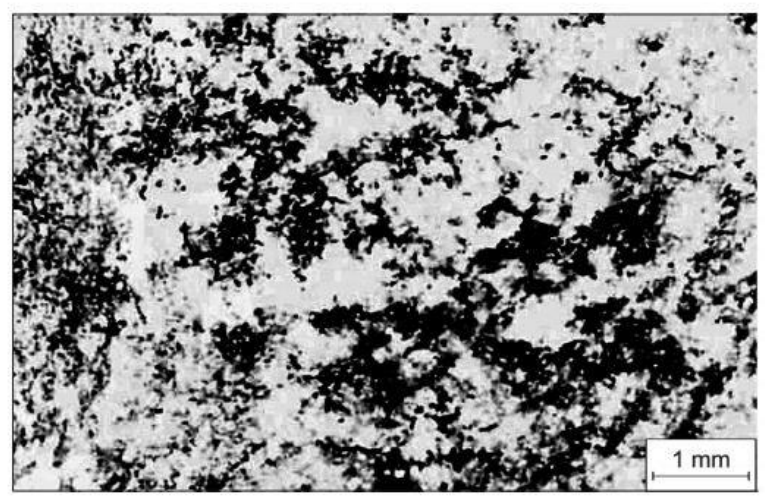

a)

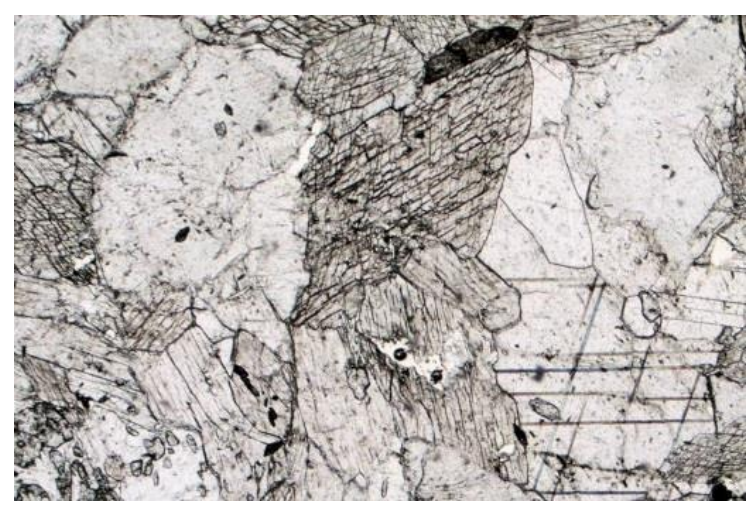

b)

Fig.1. Appearance of the organogenic limestone structure: a) macroscopic, b) microscopic $(100 \times)$ 
The macroscopic appearance of the rock is a stone material of the gray to gray-brown color, massive texture, uneven to chip fracture with fine roughness of broken surface and sharp edges of fracture. It is intensively tectonized, sprinkled with larger and smaller veins that are connected (marked with limonite) and filled with calcite measuring up to $2[\mathrm{~mm}]$. In the mass of the rock, clay-filled styols are also observed, such as nests of calcite of dimension up to $1.5 \times 0.8$ [mm]. The rock reacts violently with a five-percent solution of hydrochloric acid.

The microscopic appearance of the rock is a stone material composed of fragments of microcrystalline and organogenic limestone with traces of oligotrophic limestone and a significant amount of fossil remains bound with sparite cement. The fragments of microcrystalline limestones are rounded to corner shaped, while fragments of organogenic limestone are rounded and formed from fossil residues bound by micritic binder, partially recrystallized into microcrystalline calcite. Rare fragments of oolytic limestone were formed from oolites in the size of about $0.2[\mathrm{~mm}]$ bound by the micritic binder. Fossil remains of organisms are usually large up to $4[\mathrm{~mm}]$, with preserved skeletal forms or recrystallized crystalline calcite. Of the secondary ingredients, there is lemonite, which is finely dispersed in the grains of microcrystalline and crystalline calcite.

\subsection{Dolomite marble - site "Samar"}

This site is mainly consisting of the dolomite marble, Figure 2. The structure of this rock is granoblastic. The texture is massive and noncompact.

The macroscopic appearance of the rock is a stone material of the gray to gray-yellow, massive to tectonized texture, uneven broken surfaces with coarse roughness and sharp edges of the fracture surfaces. It is intensively tectonized, which is manifested by the presence of a large number of larger and smaller veins white to yellow-white color, which are bound (marked) with limonite and filled with calcite.

The microscopic appearance of the rock is the stone material of the isometric grains of dolomites of a uniform size that mosaically grow together. The grain size varies and the largest number of them is from $0.5 \times 0.2[\mathrm{~mm}]$, while the appearance of recrystallization is noticeable over the layers (inhomogeneities). The calcite is present in small amounts and appears in the form of irregular pileup nests. Quartz and metallic minerals are present as the secondary minerals, as well as the secondary limonite that connects the present veins in the wall.

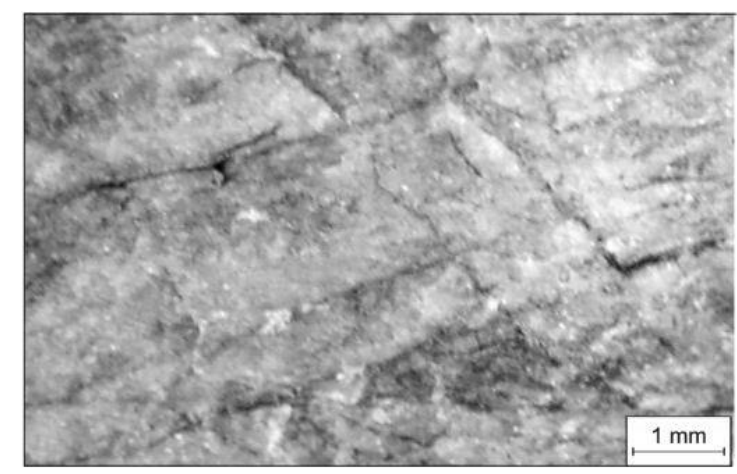

a)

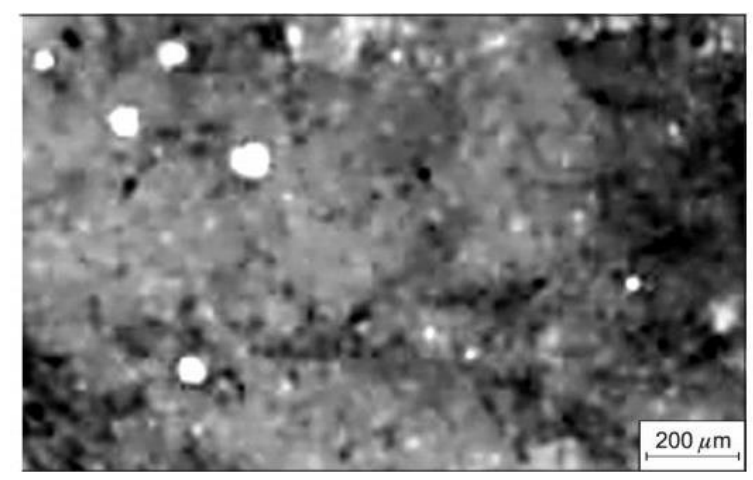

b)

Fig.2. Appearance of the dolomite marble structure: a) macroscopic, b) microscopic

\subsection{Calcite-dolomite marble - site "Gradac"}

This site is mainly consisting of the dolomite marble, Figure 3 . The structure of this rock is granoblastic. The texture is homogeneous and compact.

The macroscopic appearance of this rock is a white stone material of homogeneous texture; the broken surface is flat with coarse roughness and moderately sharp edges of the fracture.

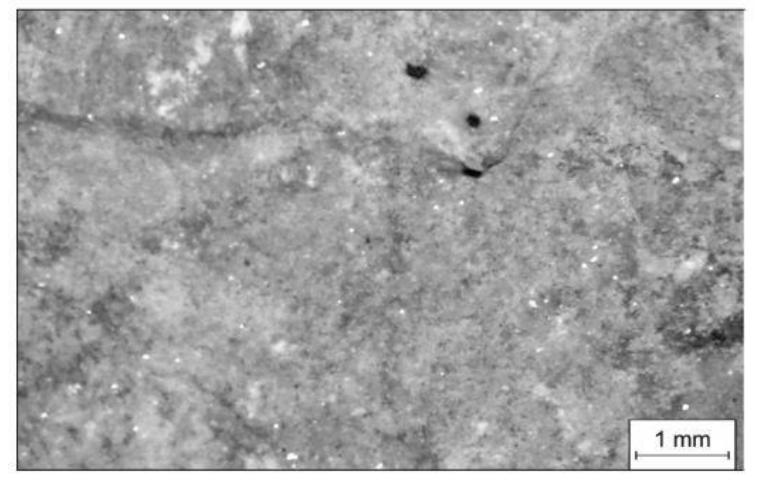

a) 


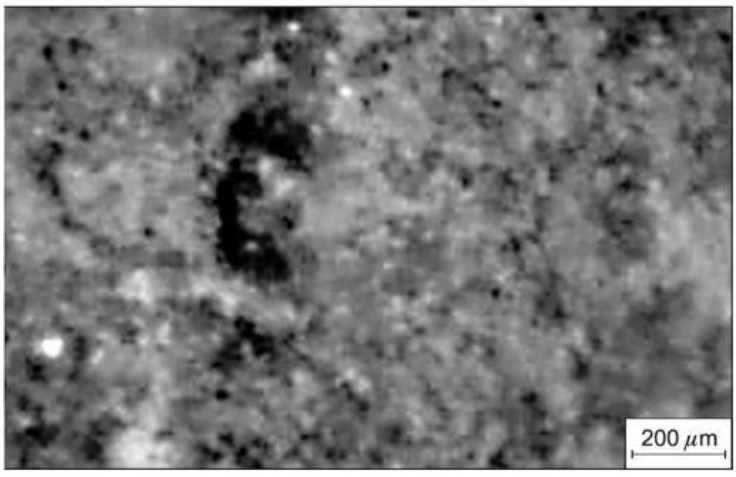

b)

Fig.3. Appearance of the calcite-dolomite marble structure: a) macroscopic, b) microscopic

The microscopic appearance of the rock is a stone material composed of crystalline dolomite connected by the calcite cement (about 90\%), grain size $0.5 \times 1.0[\mathrm{~mm}]$. About $10 \%$ are smaller grains of dolomite of the size of 0.1-0.3 [mm] and a small part of the blade muscovite (about $0.5 \%$ ) in the size of $0.2 \times 0.3[\mathrm{~mm}]$.

\subsection{Andesite - site "Šavnik"}

This site mainly consists of various kinds of andesite, Figure 4 . The structure of the rock is hollo-crystallite-porphyritic; its texture is massive.

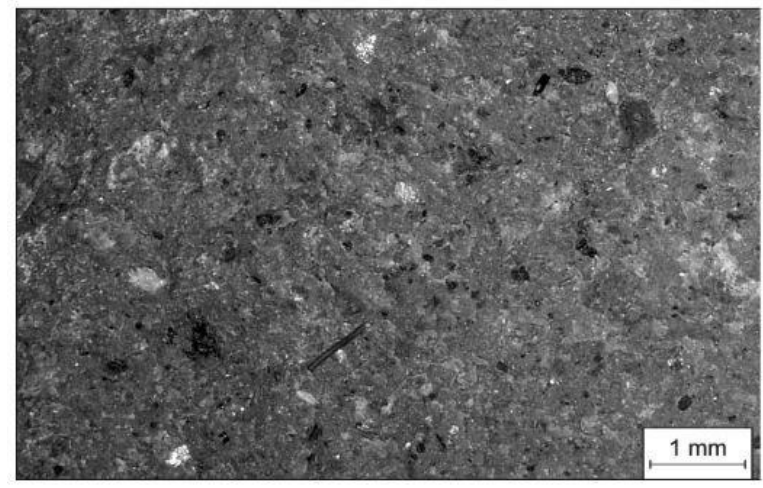

a)

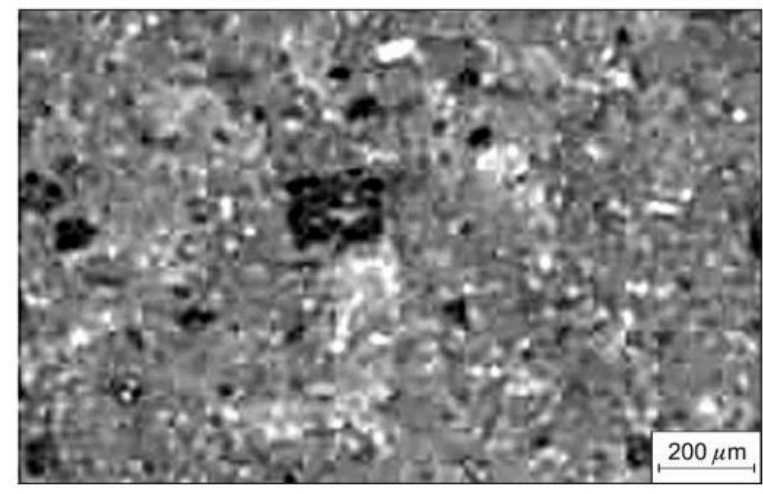

b)

Fig.4. Appearance of andesite structure: a) macroscopic, b) microscopic
The macroscopic appearance of the rock is the stone material of the gray-green color, massive texture and porphyritic structure and the colored phenocrystals, of the most commonly idiomorphic forms, up to 4 [mm] in size, are also observed. The broken surface of the rock is irregular and of the coarse roughness with extremely sharp edges of fracture.

The microscopic appearance of the rock is a stone material composed of phenocrystal plagioclasblende and biotite, which lie in the holocrystalline basic rock mass. Calcite and quartz, in the form of isometric crystals, appear as the secondary minerals in the rock.

\section{DETERMINATION OF PHYSICAL PROPERTIES OF INVESTIGATED ROCK MATERIALS}

\subsection{Experimental procedure}

Physical properties of rocks are classified in several groups: optical, hydro-physical, thermal, electrical, radioactive, etc. Optical properties of rocks are usually defined by their color, which is caused by the chemical composition of their constituent minerals. They are divided in light SAL rocks and dark - FEM rocks. The light minerals are rich in aluminum and silicon, while the dark ones are rich in iron and magnesium. The hydrophysical properties of rocks are specific mass (density), volumetric mass, porosity, compactness, compressibility, water absorption, humidity, capillary, stickiness, swelling, ventilation, $[2,16-$ 17].

The largest difference in porosity and water absorption possess various types of limestone, sandstone and andesite. In water-saturated samples, for majority of rock materials, the compression strength is decreased, the softening of rocks occurs. However, there are some types of rocks for which this property is improved by water absorption, like rock materials bihacite and basalt, where the compressive strength increases for 15 $\%$ and $40 \%$, respectively. The rock materials for which the softening coefficient is greater than 40 $\%$ are not suitable for commercial use.

Of all the physical properties of the firmly bound rocks (stones) and their aggregates, the most experimentally investigated ones are the specific mass (density), volumetric mass, porosity, water absorption and compactness. Other physical properties are seldom tested, i.e. only in the case of some specific use. Physical properties 
of rocks directly influence their mechanical and technological properties.

Determination of the volumetric mass is usually done with samples of the regular form (cube, prism, etc.), with the smallest dimension no less than 40 [mm]; for samples of the irregular shape the minimal size is 150 [mm]. In this experiment, five samples in the shape of a cube, edge size $50 \pm$ 0.1 [mm], were used for each type of rocks; tests were performed at room temperature $20 \pm 2{ }^{\circ} \mathrm{C}$ and drying of samples was done at temperature of $105 \pm 5^{\circ} \mathrm{C}$.

Determination of the rock density was done by measuring the dried powder of the mineral mass, in quantity of about $50 \mathrm{~g}$, which has to pass through the sieve with eyelet of $0.09[\mathrm{~mm}]$, without any residue. The minimum number of measurements for this test was three.

\subsection{Volumetric mass}

The volumetric (volume) mass of rocks is the mass of solid particles with pores and voids in a unit of the total volume is $\chi_{N}=m_{s} / V,\left[\mathrm{~kg} / \mathrm{m}^{3}\right]$, where $m_{\mathrm{s}},[\mathrm{kg}]$ is the mass of the dry sample and $V,\left[\mathrm{~m}^{3}\right]$, is the total volume of the dry sample.

According to values of the volumetric mass, the rocks are classified as:

$$
\begin{aligned}
& \text { - very light }-\mathcal{W}=1000-1500\left[\mathrm{~kg} / \mathrm{m}^{3}\right] \text {, } \\
& \text { - } \quad \text { light }-\gamma=1500-2500\left[\mathrm{~kg} / \mathrm{m}^{3}\right] \text {, } \\
& \text { - massive }-\mathcal{N}=2500-3000 \mathrm{~kg} / \mathrm{m}^{3} \text { and } \\
& \text { - } \quad \text { very massive }-\mathcal{w}>3000\left[\mathrm{~kg} / \mathrm{m}^{3}\right] \text {. }
\end{aligned}
$$

Knowing the volumetric mass of rocks is extremely important for design and building of civil constructions, as well as for exploitation of the construction machinery, especially during the loading, transport and unloading of these construction materials. Values of volumetric mass for some kinds of rocks are presented in Figure 5.

Results of tests are presented in Table 2 and Figure 6 . The tested rocks can be classified as massive.

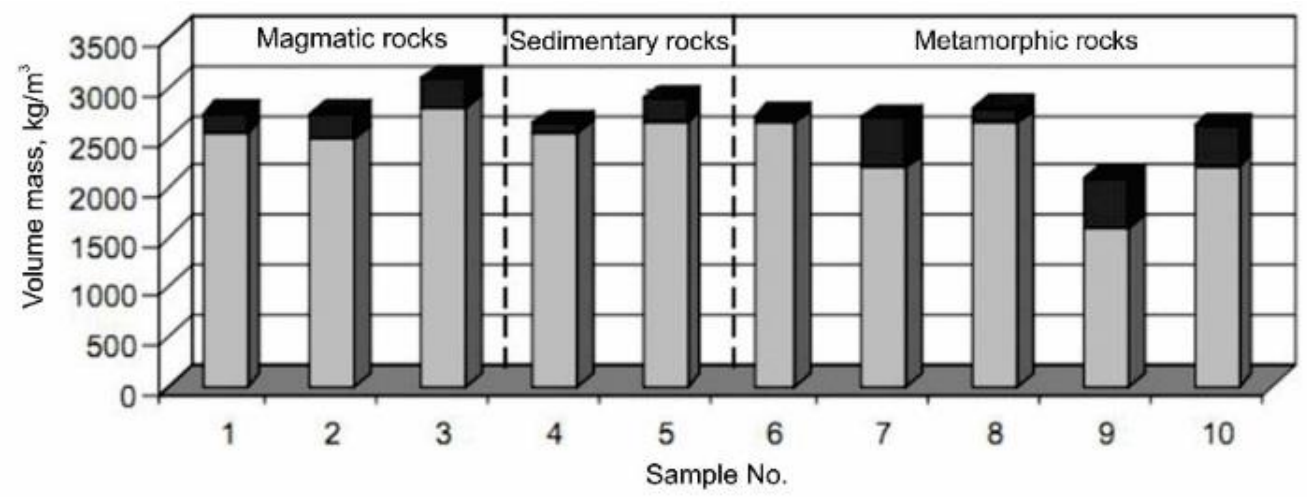

Fig.5. Volumetric mass of several types of rocks in natural state: 1 - granite, granodiorite, quartz-porphyritic; 2 dacite, andesite, porphyrite; 3 - gabbro, basalt, diabase; 4 - gneiss, mikaşist, phyllite; 5 - serpentinite; 6 - marble onyx; 7 - limestone; 8 -dolomite; 9 -tufa; 10 - sandstone

Note: full height columns denote results for the wet samples, while the grey portions denote results for the dried samples.

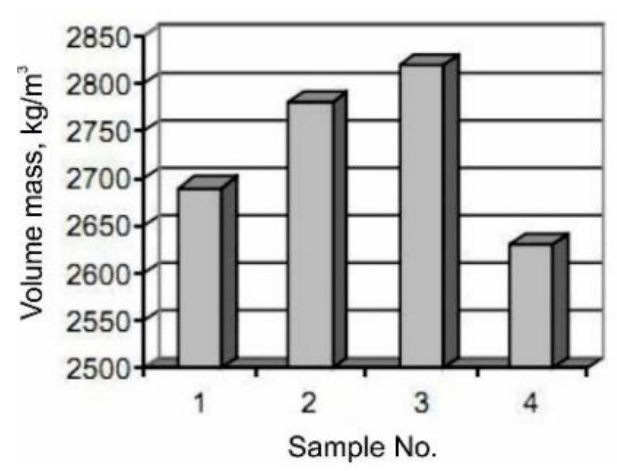

Fig.6. Results of volumetric mass tests: 1 - Limestone, 2 - Dolomite marble, 3 - Calcite-dolomite marble, 4 Andesite

\subsection{Specific mass (density)}

The specific mas (density) of a rock is the mass of its mineral particles in the volume unit, without the pores and voids, $\rho_{S}=m_{s} / V_{s},\left[\mathrm{~kg} / \mathrm{m}^{3}\right]$, where $m_{\mathrm{s}},[\mathrm{kg}]$, is the mass of the dry mineral substance and $V_{s},\left[\mathrm{~m}^{3}\right]$, is the volume of the dry mineral substance.

Obtained results for four tested types of rocks are shown in Figure 7 and Table 2, $[2,18]$.

The volumetric mass coefficient values, calculated as the ratio of the volumetric mass and the density of the rock, $i=\gamma_{\mathrm{v}} / \rho_{\mathrm{s}}$, are also presented in Table 2. 
Table 2. Volumetric and specific mass of tested samples of four types of rocks: 1 - Limestone (Vučjak), 2 - Dolomite marble (Samar), 3 - Calcite-dolomite marble (Gradac), 4 - Andesite (Šavnik).

\begin{tabular}{|c|c|c|c|c|}
\hline \multirow{2}{*}{ Tested property } & \multicolumn{4}{|c|}{ Type of rock and site } \\
\cline { 2 - 5 } & 1 & 2 & 3 & 4 \\
\hline Volumetric mass, $\mathrm{kg} / \mathrm{m}^{3}$ & 2690 & 2780 & 2820 & 2630 \\
\hline Density, $\mathrm{kg} / \mathrm{m}^{3}$ & 2730 & 2870 & 2850 & 2750 \\
\hline Volumetric mass coefficient & 0.985 & 0.969 & 0.989 & 0.956 \\
\hline
\end{tabular}

\subsection{Porosity}

The rock porosity represents the total empty space within the volume unit, which is not filled with the mineral substance. It depends on the structure and texture of rocks, namely on the size of grains and ways of their packing (aggregation) within the rock. The porosity is calculated from expression $p=\left[1-\left(\gamma_{s} / \rho_{s}\right)\right] \cdot 100 \%$. According to the total porosity value, firmly bound (stone) rocks are divided into poorly porous ( $p=1.0-2.5 \%$ ); porous ( $p=2.5-5.0 \%)$; quite porous ( $p=5-10 \%)$; very porous ( $p=10-20 \%$ ) and extremely porous ( $p>20 \%),[2,19-21]$. The usual values of total porosity for several types of rocks are presented in Figure 8. Analysis of porosity points to the fact that it is the most important property of rocks since it directly influences the volumetric mass and water absorption of different types of rocks.

The highest difference of porosity is found in different kinds of limestones, because the porosity is influenced by types of voids. The porosity can be isolated, when the voids are mutually isolated, or effective, when the voids in rocks are connected.

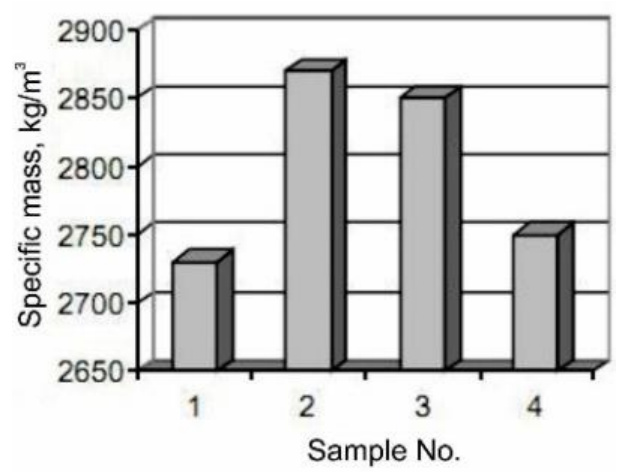

Fig.7. Results of specific mass tests: 1 - Limestone, 2 Dolomite marble, 3 - Calcite-dolomite marble, 4 Andesite

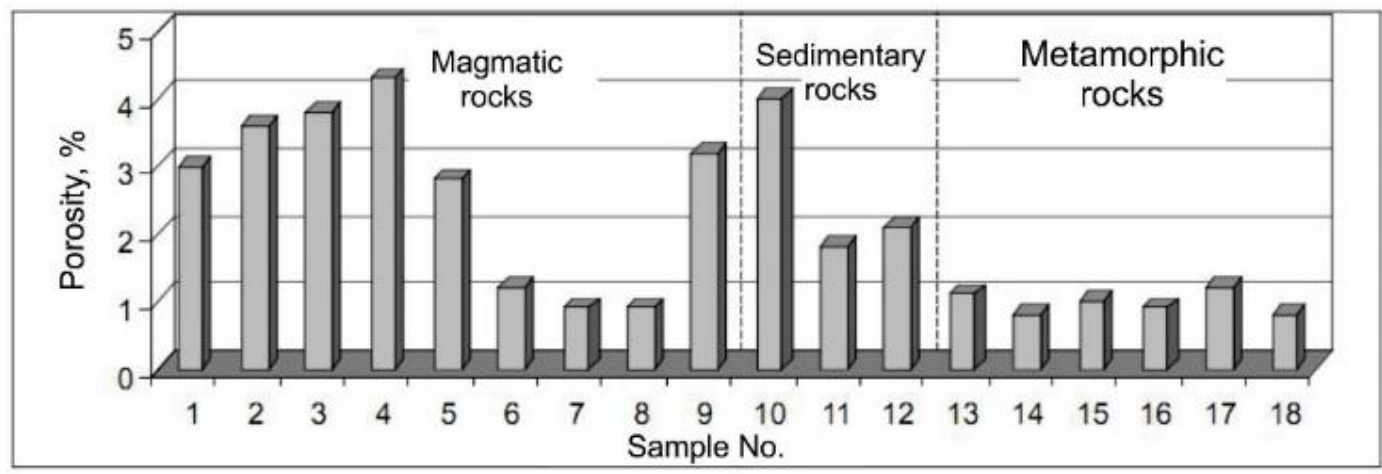

Fig.8. Porosity of various types of rocks: 1 - rhyolite, 2 - trachyte, 3 - dacite, 4 - andesite, 5 - basalt, 6 - granite, 7 diabase, 8 - gabbro, 9 - diorite, 10 - sandstone, 11 - limestone, 12 - dolomite, 13 - gneiss, 14 - mikaşist, 15 -phyllite, 16 - marble, 17 - quartzite, 18 - amphibolite

\subsection{Water absorption}

The water absorption of rocks is a property that significantly affects their physical and mechanical properties. It represents the ability of a rock to absorb certain quantity of water, up to its natural humidity. Water absorption is defined by the ratio of the water mass and the solid mineral substance mass. For different types of rocks it is defined as $w=\left[\left(m_{v}-m_{s}\right) / m_{s}\right] \cdot 100, \%$, where $m_{\mathrm{v}}$ is the mass of water and $m_{\mathrm{s}}$ is the mass of the dry substance. Results of experimental investigations of porosity and the water absorption are presented in Table 3 and in Figures 9 and 10, respectively, [2, 22-24].

The tests have shown that organogenic limestone and calcite-dolomite marble belong into a group of poorly porous rocks, while the dolomite marble and andesite are the porous rocks. 
Porosity and water absorption are the most tested properties because they affect the compactness of rocks. The smallest possibility for compacting exhibit those rocks that possess the smallest values of these two properties. The possibility for compacting is influenced by the strength of cohesive bonds between the rock's constitutive mineral grains, as well. Rocks with stronger cohesive bonds have smaller compactness due to aggravated extrusion of absorbed water.

Table 3. Results of porosity and water absorption tests: 1 - Limestone, 2 - Dolomite marble, 3 - Calcitedolomite marble, 4 - Andesite

\begin{tabular}{|c|c|c|c|c|}
\hline \multirow{2}{*}{ Tested property } & \multicolumn{4}{|c|}{ Rock type } \\
\cline { 2 - 5 } & 1 & 2 & 3 & 4 \\
\hline Porosity, \% & 1.50 & 3.10 & 1.10 & 4.40 \\
\hline Water absorption, \% & 0.18 & 0.17 & 0.12 & 0.64 \\
\hline
\end{tabular}

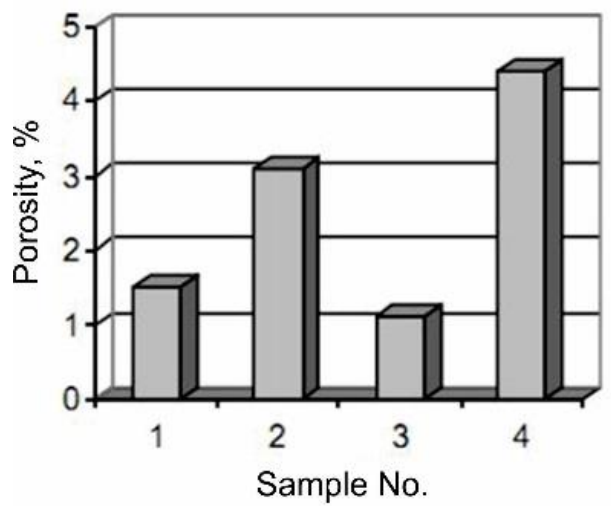

Fig.9. Results of porosity tests for selected types of rocks: 1 - Limestone, 2 - Dolomite marble, 3 -Calcitedolomite marble, 4 - Andesite

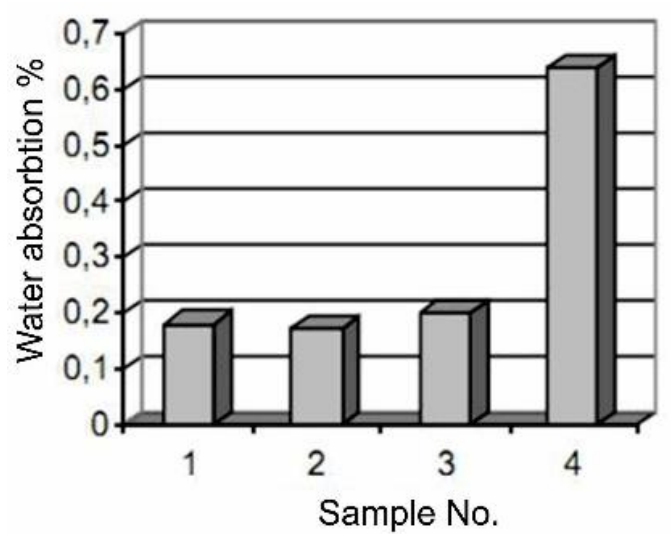

Fig.10. Results of water absorption tests for selected types of rocks: 1 - Limestone, 2 - Dolomite marble, 3 Calcite-dolomite marble, 4 - Andesite

\section{UTILIZATION OF TESTED ROCK MATERIALS}

The tested rock materials are applied as building materials, in different branches of the constructions industry.

Limestone is used for manufacturing lime, which has various usage in building industry. The dolomite marble is used as decorative stone, as the raw material for producing the cement (as gravel) and as a source of magnesium oxide, as well as elementary magnesium. The ground dolomite marble is also used as the raw material for producing ceramics. Andesite, which is abundant in Serbia, is used as a construction material for roads that are subjected to intensive traffic loads. It can also be used as a carrier of sulfidic mineralization.

\section{SUMMARY AND CONCLUSIONS}

In this paper are presented results of considering the petrographic properties and testing the physical properties of four types of rocks found at four sites in Republic of Serbia, namely: limestone from the site "Vučjak", dolomite marble from the site "Samar", calcitedolomite marble from the site "Gradac" and andesite from the site "Šavnik". Those four types of rock materials are the most frequently used for the road constructions.

The analyzed petrographic properties of the selected rock materials were mineralogical composition, structure and texture. Structures of the tested rock materials were different, textures were homogeneous, massive and compact, except for the dolomite marble, whose texture was massive but incompact.

The physical properties that were tested included the specific mass (density), volumetric mass, porosity and water absorption. The four tested rock materials belong into a group of the massive rocks with various porosities and water absorption. The lowest porosity was exhibited by the calcite-dolomite marble, which can be classified as poorly porous rock material; the same goes for the organogenic limestone, while the dolomite marble and andesite can be classified as porous and moderately water absorbent.

Knowing various properties of different building materials, is important for their use in the construction industry, as well as for their manufacturing (processing) and transport. That 
secures the adequate design, manufacturing and exploitation of the construction mechanization, especially the elements that are in direct contact with the rock materials.

Note: The shorter version of this research was presented at The $25^{\text {th }}$ International Seminar of Ph.D. Students SEMDOK 2020, reference [25].

\section{Acknowledgments}

This research was partially financially supported by the project of Operational Program Research and Innovation: "Research and development activities of the University of Žilina in the Industry of 21st century in the field of materials and nanotechnologies", No. 313011T426, co-funded by the European Regional Development Fund and by the project TR35024 funded by the Serbian Ministry for Science, Education and Technological development.

\section{REFERENCES}

[1] V. Lazić, D. Arsić, R. Nikolić, B. Hadzima, M. Mutavdžić, Experimental determination of mechanical characteristics of four types of stones and their influence on the construction machinery parts wear. Advanced Materials Research, 1100, 2015: 178-184.

https://doi.org/10.4028/www.scientific.net/ AMR.1100.178

[2] M. Mutavdžić, Modeling of the reparatory and manufacturing hard facing of the construction mechanization (Ph.D. Thesis). Faculty of Engineering, University of Kragujevac, Kragujevac, Serbia, 2015.

[3] M.R. Smith, Stone: building stone, rock fill and armor stone in construction. Engineering geology Special publication No. 1. Tulsa, OK. US Geological Society Publishing House, 1999.

[4] M. Janjić, Fundamentals of geology and engineering geology - the first part. Faculty of Civil Engineering, Belgrade, Serbia, 1964. (In Serbian).

[5] M. Muravljov, Construction material. Civil Engineering Book, Belgrade, Serbia, 2002. (In Serbian)

[6] M. Mutavdžić, R. Čukić, M. Jovanović, D. Milosavljević, V. Lazić, Model investigations of the filler materials for regeneration of the damaged parts of the construction mechanization. Tribology in Industry, 30(3), 2008: 3-9.

[7] D. Arsić, V. Lazić, S. Mitrović, D. Džunić, S. Aleksandrović, M. Djordjević, B. Nedeljković, Tribological behavior of four types of filler metals for hard facing under dry conditions. Industrial Lubrication and Tribology, 68(6), 2016: 729-736.

https://doi.org/10.1108/ILT-10-2015-0156

[8] J.C. Li, T.T. Liu, H.B. Li, Y.Q. Liu, B. Liu, X. Xia, Shear wave propagation across filled joints with the effect of interfacial shear strength. Rock Mechanics and Rock Engineering. 48, 2015: 1547-1557.

https://doi.org/10.1007/s00603-014-0662-1

[9] N. Barton, The shear strength of rock and rock joints. International Journal of Rock Mechanics and Mining Sciences and Geomechanics Abstracts, 13(9), 1976: 255279.

[10] E. Komurlu, A. Kesimal, Evaluation of indirect tensile strength of rocks using different types of jaws. Rock Mechanics and Rock Engineering, 48(4), 2015: 1723-1730.

https://doi.org/10.1007/s00603-014-0644-3

[11] J. E. Lindqvist, U. Akesson, K. Malaga, Microstructure and functional properties of rock materials. Materials Characterization, 58(11), 2015: 1183-1188.

https://doi.org/10.1016/i.matchar.2007.04.0 $\underline{12}$

[12] E.T. Mohamad, R. Saad, N. Nazim, B. Hamzah, S. Norsalkini, M.A. Tan, M. Liang, Assessment on abrasiveness of rock material on the wear and tear of drilling tool. Electronic Journal of Geotechnical Engineering, 17(A), 2012: 91-100.

[13] X. Liu, P. Tang, X. Li, M. Tian, Self-rotatory performance of conical cutter interacted with rock material. Engineering Failure Analysis, 80, 2017: 197-209.

https://doi.org/10.1016/j. engfailanal.2017. $\underline{06.030}$

[14] S. Liu, H. Ji, X. Liu, H. Jiang, Experimental research on wear of conical pick interacting with coal-rock. Engineering Failure Analysis, 74, 2017: 172-187.

https://doi.org/10.1016/j.engfailanal.2017.0 $\underline{1.013}$ 
[15] Q. Wang, R. Pan, B. Jiang, S.C. Li, M.C. He, S.B. Sun, Q. Wang, Q. Qin, H.C. Yu, Y.C. Luan, Study on failure mechanism of roadway with soft rock in deep coal mine and confined concrete support system. Engineering Failure Analysis, 81, 2017: 155-177.

https://doi.org/10.1016/j.engfailanal. 2017.08.003

[16] R.J. Alfred, Rock Mechanics, 2nd ed. Clausthal: Trans Tech Publication, 1983.

[17] R. Ulusay, (Ed.) The ISRM Suggested Methods for Rock Characterization, Testing and Monitoring. Pergamon Press; London, UK, 1987.

[18] R. Bertuzzi, Revisiting rock classification to estimate rock mass properties. Journal of Rock Mechanics and Geotechnical Engineering, 11(3), 2019: 494-510. https://doi.org/10.1016/j.jrmge.2018.08 .011

[19] K.L. Milliken, M.E. Curtis, Imaging pores in sedimentary rocks: Foundation of porosity prediction. Marine and Petroleum Geology, 73, 2016: 590-608.

https://doi.org/10.1016/j.marpetgeo.2016.0 3.020

[20] S.L. Allshorn, R.A. Dawe, C.A. Grattoni, Implication of heterogeneities on core porosity measurements. Journal of Petroleum Science and Engineering, 174, 2019: 486-494.

https://doi.org/10.1016/j.petrol.2018.11.045

[21] J.B. Regnet, C. David, P. Robion, B. Menéndez, Microstructures and physical properties in carbonate rocks: A comprehensive review. Marine and Petroleum Geology, 103, 2019: 366-376.

https://doi.org/10.1016/j.marpetgeo. 2019. 02.022

[22] Y.J. Zhuang, H.Z. Yu, Q.Y. Zhu, Experimental and numerical investigations on the flow around and through the fractal soft rocks with water vapor absorption. International Journal of Heat and Mass Transfer, 96, 2016: 413-429.

https://doi.org/10.1016/i.ijheatmasstransfer .2016 .01 .025

[23] L. Dejian, W. Guilian, H. Liqiang, L. Peiyu, H. Manchao, Y. Guoxing, T. Qimin, C. Cheng, Analysis of microscopic pore structures of rocks before and after water absorption. Mining Science and Technology (China), 21(2), 2011: 287-293.

https://doi.org/10.1016/j.mstc.2011.02.002

[24] S. Scrivano, L. Gaggero, J.G. Aguilar, Microporosity and minero-petrographic features influences on decay: Experimental data from four dimension stones. Construction and Building Materials, 173, 2018: 342-349.

https://doi.org/10.1016/i.conbuildmat.2018. 04.041

[25] D. Arsić, M. Mutavdžić, R.R. Nikolić, V. Lazić, B. Hadzima, Physical properties of selected rock materials, The $25^{\text {th }}$ International Seminar of Ph.D. Students SEMDOK 2020, O. Bokuvka and P. Palček (Ed.), January 29-31, 2020, Zuberec, Slovakia, pp. 9-14. 